\title{
The use of citrus pulp silage in Diplodus puntazzo nutrition
}

\author{
Silvia Nogales-Mérida ${ }^{1,2,4} \oplus$. Ana Tomás-Vidal ${ }^{1} \cdot$ Miguel Jover Cerdá ${ }^{1} \cdot$ Nury B. Sánchez-Lozano ${ }^{5}$. \\ Jorge Velazco-Vargas $^{3} \cdot$ Silvia Martínez-Llorens $^{1}$
}

Received: 15 May 2018 / Accepted: 20 November 2018 / Published online: 27 November 2018

(C) The Author(s) 2018

\begin{abstract}
Purpose Studying the effect of citrus pulp silage in the growth performance, amino acid retention of sharpsnout sea bream juveniles.

Methods Citrus pulp is an energy and protein source that has been used to replace wheat meal in Diplodus puntazzo fingerlings; 96 fish of $21.5 \pm 0.67 \mathrm{~g}$ were nourished with two experimental diets for 105 days. The control diet (CON) contained $421.6 \mathrm{~g} / \mathrm{kg}$ of protein and $22.6 \mathrm{MJ} / \mathrm{kg}$ of energy. The citrus pulp diet (CPD) included $442.7 \mathrm{~g} / \mathrm{kg}$ of protein and $22.02 \mathrm{MJ} /$ $\mathrm{kg}$ of energy.

Results At the end of this trial, the CPD did not affect the growth parameters, but the feed efficiency values exhibited statistically significant differences, with those fish fed the CPD having higher values, possibly due to the presence of limonene in the diet. The CPD also resulted in a reduction in amino acid (AA) content due to the protein being bound to fibre; this consequence did not affect the final fish AA profile. For AA retention, only arginine displayed significant differences, although the rest of the AAs also showed effects of AA reduction from the CPD.

Conclusion Citrus pulp silage can be used in D. puntazzo feeding, without adverse in the growth performance and the amino acid profile, although it did cause a reduction in feed efficiency.
\end{abstract}

Keywords Diplodus puntazzo $\cdot$ Amino acids $\cdot$ Citrus pulp $\cdot$ Retention $\cdot$ Ensiled $\cdot$ Wheat meal

\section{Introduction}

Worldwide production of citrus has constantly increased in the last years from 116.128 thousand tonnes $(\mathrm{kt})$ in 2008 to $124.246 \mathrm{kt}$ in 2016 (FAO 2017). According to Spreen (2001), this growth has been based more on processed fruit

Silvia Nogales-Mérida

silnoga@cobaltus.com

1 Aquaculture and Biodiversity Group, Institute of Animal Science and Technology (ICTA), Universitat Politècnica de València, Camino de Vera s/n, 46022 Valencia, Spain

2 Department of Animal Nutrition, Poznan University of Life Sciences, Wolyńska 33, 60-637 Poznan, Poland

3 Faculty of Environmental Science, Pontifical University Catholic of Ecuador in Esmeraldas (PUCESE), C/Espejo, Subida a Santa Cruz s/n, 080150 Esmeraldas, Ecuador

4 HiProMine, S.A., 62-023 Robakowo, Poland

5 Programa de Zootecnia, Facultad de Ciencias Agrarias, Universidad de Cundinamarca, C/18, Fusagasugá 2029, Colombia consumption such as orange juice than fresh fruit consumption. This author foresees that this trend will pursue in the future years, so in the same way, the citrus by-product will continue their increment.

One of the main worldwide citrus by-products is citrus pulp. It is obtained from the entire residue after juice extraction. Parts of the citrus pulp are the peel, the remnant and the seeds of the fruit. According to Piquer et al. (2009), Shan (2017) and Wang et al. (2017), citrus byproducts are composed of one type of citrus (oranges, mandarins, lemons or grapefruits) or a mix of these fruits. This combination makes that the final product differs in their chemical composition (Basir and Togayani 2017; Marín et al. 2007). As stated by Lashkari and Taghizadeh (2012), the composition of citrus pulp can vary in bromatological composition, depending on the sources, which could be lemon, tangerine, orange and/or grapefruit: carbohydrates make up the highest portion of citrus pulp (81.51-85.13\%), and there is also crude protein (CP) (6.64-9.54\%), crude lipid (CL) (2.38-3.44\%), neutral detergent fibre (10.88-21.23\%), acid detergent fibre 
(8.48-17.04\%) and hemicellulose (1.55-4.19\%). Besides, $20-30 \%$ of dried weight of citrus peel is composed by pectin (Shan 2017), which is a non-starch polysaccharide that is part of the natural diet of herbivorous and omnivorous fish (Krogdahl et al. 2005). In addition, the citrus pulp composition contains tannin, saponin, phytate, oxalate, flavonoid, and limonene (Oluremi et al. 2010); regarding tannins, phytate and oxalate are known to affect protein and mineral utilisation in fish nutrition (Francis et al. 2001).

In general, the citrus pulp residue that industries produce is transformed into silage. Silage is commonly used as a raw material in cattle and sheep nutrition with good results in terms of milk production (Piquer et al. 2009) and animal growth (Alnaimy et al. 2017). In the last few decades, the use of silage has extended to nutrition for monogastric animals, such as pigs (Amorim et al. 2011, 2014; Crosswhite et al. 2013; Watanabe et al. 2009, 2010) and chickens (Mourão et al. 2008; Silva et al. 2013), with no adverse growth parameters. In fish nutrition, silage has been tested in two continental fish, Oreochromis niloticus (Moreno Alvarez et al. 2000) and Rhamdia quelen (Rodriguez et al. 2012). In marine species, silage has also been tested as an antioxidant to improve the fillet quality of Seriola quinqueradiata (Fukada et al. 2014), obtaining the best results with a $10 \mathrm{~g} / 1450 \mathrm{~g}$ diet (wet basis).

On the side, sharpsnout sea bream (Diplodus puntazzo) is a marine and omnivorous species. Parts of their natural diet are algae, crustaceans and polychaetes (Chaouch et al. 2013; Saleh and El-Mor 2015), which they consume seasonally. As an omnivorous fish, the sharpsnout can obtain a good growth rate with a low ratio of protein/ energy (19.67); using in great part carbohydrates as energy sources (Hernández et al. 2001), which has made it one of the alternative fish in the Mediterranean region.

Citrus pulp as an energy source in marine fish nutrition has not been studied previously, and for that reason, the aim of this experiment was to study the use of citrus pulp silage in juveniles of $D$. puntazzo, observing the growth, feed efficiency and biometric parameters, as well as the amino acids, profile, and retention.

\section{Materials and methods}

\section{Ethics statements}

The protocols of this experiment were revised and approved by the Committee of Ethics and Animal Welfare of the Universitat Politècnica de València (UPV), following the Spanish Royal Decree 53/2013 for the protection of animals used for scientific purposes.

\section{Diets}

The citrus pulp silage was a product made up, in large part, of the silage of orange pulp. The pulp was very well triturated allowing easy silage. After 20 days, the $\mathrm{pH}$ of the citrus pulp was stabilized in 3.5 , and then it was dried and ground.

The main ingredients (fish meal, wheat and citrus pulp meal) are presented in Table 1 and the essential and nonessential amino acids used in the tested diets are shown in Table 2 consecutively. The two tested diets were formulated by replacing wheat (CON) with citrus pulp (CPD) (Table 2). The diets were extruded, using a semi-industrial twin-screw extruder (CLEXTRAL BC-45, St. Etienne, France). This is an extrusion cooking process, where the conditions to process the diets were: $100 \mathrm{rpm}$ speed screw, with a maximum heat temperature of $110^{\circ} \mathrm{C}$, reaching 40-50 atm pressure. The pellet diameter was $2 \mathrm{~mm}$.

\section{Production system and water quality}

The experiment occurred in the Nutrition Department of the Aquaculture laboratory. The experiment was set up in a saltwater recirculation system, using two cylindrical $750 \mathrm{~L}$ fibreglass tanks. All along the experimental period, the water quality parameters were as follows: water temperature $22.4 \pm 2.2{ }^{\circ} \mathrm{C}$; minimum dissolved oxygen was $6.3 \mathrm{mg} \mathrm{L}^{-1}$; the mean $\mathrm{pH}$ values were 7.4 , the $\mathrm{NH}_{4}^{+}$value

Table 1 Proximate composition of experimental diets

\begin{tabular}{|c|c|c|}
\hline Ingredients (g/kg) & Control diet & Citrus pulp diet \\
\hline Fish meal, herring $(5-02-000)$ & 571 & 567 \\
\hline Dry citrus pulp & 0 & 234 \\
\hline Wheat (4-05-268) & 226 & 0 \\
\hline Soybean oil & 51 & 50 \\
\hline Fish oil (7-08-048) & 92 & 90 \\
\hline Maltodextrin & 50 & 49 \\
\hline Vitamin-mineral mix ${ }^{a}$ & 10 & 10 \\
\hline
\end{tabular}

All analyses were done in the feed nutrition laboratory belonging to Animal Science Department of the Universitat Politècnica de València

${ }^{\mathrm{a}}$ Vitamin and mineral mix (values are $\mathrm{g} / \mathrm{kg}$ except to those in parenthesis): premix 20; choline 10; DL- $\alpha$-tocopherol 5; ascorbic acid 5; premix composition: retinol acetate $(1,000,000 \mathrm{IU} 7 \mathrm{~kg})$; calciferol (500 IU kg ${ }^{-1}$ ); DL- $\alpha$-tocopherol 10 ; menadione sodium bisulphite 0.8 ; thiamin hydrochloride 2.3 ; riboflavin 2.3 ; pyridoxine hydrochloride 15; canocobalamin 25; nicotinamide 15 ; pantothenic acid 6 ; folic acid 0.65 ; biotin 0.07 ; ascorbic acid 75 ; inositol 15 ; betaine 100 ; polypeptides 12; Zn 5; Se 0.02; I 0.5; Fe 0.2; Cuo 15; Mg 5.75; Co 0.02; Met 0.2; Cys 0.8; Lys 1.3; Arg 0.6; Phe 0.4; Try 0.7; except to $1000 \mathrm{~g}$ (source: Dibaq-Diproteg) 
Table 2 The bromatological composition of the raw material and experimental diets, expressed in dry matter $(\%)$

\begin{tabular}{lcrccc}
\hline & Fish meal & Wheat & Citrus pulp silage & Control diet & Citrus pulp diet \\
\hline Dry matter (DM) & 91.14 & 88.10 & 95.21 & 91.99 & 91.70 \\
Crude protein (CP) & 74.51 & 10.90 & 11.88 & 42.16 & 44.27 \\
Crude lipid (CL) & 9.31 & 1.79 & 3.55 & 18.80 & 19.83 \\
N-free extract (NFE) & 0.0 & 81.97 & 62.90 & 28.52 & 20.18 \\
Ash & 16.75 & 2.08 & 5.75 & 10.04 & 12.17 \\
Crude fibre (CF) & 1.00 & 3.25 & 15.92 & 0.48 & 3.55 \\
GE (MJ/kg) & 21.51 & 17.92 & 15.32 & 22.6 & 22.02 \\
CP/GE (g/MJ) & 34.63 & 7.31 & 7.75 & 20.77 & 20.10 \\
\hline
\end{tabular}

a $\% \mathrm{NFE}=100-(\% \mathrm{CP}-\% \mathrm{CL}-\%$ ash $-\% \mathrm{CF})$

${ }^{\mathrm{b}} G E$ gross energy: calculated using $23.9 \mathrm{~kJ} \mathrm{~g}^{-1}$ proteins, $39.8 \mathrm{~kJ} \mathrm{~g}^{-1}$ lipids and $17.6 \mathrm{~kJ} \mathrm{~g}^{-1}$ carbohydrates was $0.02 \mathrm{mg} \mathrm{L}^{-1}$ and the salinity value was $32.58 \mathrm{~g} / \mathrm{kg}$. The trial was done under natural light conditions, and all the tanks received similar light intensity.

\section{Fish and their distribution}

The fingerlings were acquired from a hatchery in Italy and the fish were under acclimatization for 8 weeks previously to the beginning of the trial. During that time, the fish were fed with a basic commercial diet for marine species (ECOPLUS 10) until the experiment started.

At the beginning of the experiment, three baskets per tank were used. Each basket had a 98-L capacity. Sixteen fish weighing $21 \mathrm{~g}$ (average weight) were put in each basket and fed by hand to apparent satiation with experimental diets for 105 days (March 12 to June 25). The fish were fed at 9 and $15 \mathrm{~h}, 6$ days a week.

Fish were weighed individually when the experiment started and at the end, but while the experiment occurred, the animals were weighed in number of two or three fish at once, every 3 weeks, after the fish had starved during $24 \mathrm{~h}$; the animals were anaesthetized using clove oil (Guinama ${ }^{\circledR}$, Valencia, Spain). The dose used was $30 \mathrm{mg} / \mathrm{L}$.

\section{Biometrics analysis}

At the end of this experiment, three fish per basket were killed and all the biometric parameters were collected. These data served to determinate the following values: hepatosomatic index (HSI), mesenteric fat index (MFI), viscerosomatic index (VSI); condition factor (CF) and dress-out percentage and for subsequent chemical analysis, the fish were stored at $-30{ }^{\circ} \mathrm{C}$.

\section{Proximate composition and amino acid analysis}

It determined the chemical composition of the ingredients previously to diet formulation. All the materials (experimental diets, ingredients, and whole fish) were analysed conforming to the AOAC (1990) procedures. For dry matter, the samples were kept at $105^{\circ} \mathrm{C}$ until they reach a constant weight. To determinate the ash content in the samples, they were incinerated at $550{ }^{\circ} \mathrm{C}$ until constant weight. In the case of crude protein $(N \times 6.25)$, it was determined by the Kjeldahl method after an acid digestion. The crude lipid was obtained using methyl ether in a Soxtec 1043 extraction unit. The crude fibre was obtained by acid and basic digestion (Fibertec System M., 1020 Hot Extractor, Tecator). All the analyses were performed in triplicate.

For the amino acids of raw materials, experimental diets and fish carcass, it used the technique previously described by Bosch et al. (2006). All the samples were analysed using a Waters HPLC system: this equipment consisted of two pumps, an autosampler, a fluorescence detector and a temperature control module (Model Waters 474, Waters, Mildford, MA, USA). Before hydrolysation, it was added aminobutyric, the internal standard patron. The samples were derivatized with AQC (6-aminoquinolyl- $N$-hydroxysuccinimidyl carbamate). It was determined separately methionine as methionine sulphone and cysteine as cysteic acid after oxidation with performic acid. It was used a C-18 reverse-phase column Waters Acc. Tag $(150 \mathrm{~mm} \times 3.9 \mathrm{~mm})$ to separate the amino acids.

\section{Statistical analysis}

It analysed the growth performance, feed efficiency and amino acids values using an unpaired Student's $t$ test at 0.05 significant levels. For these tests, we used free software (InfoSTAT, 1613-2013 Universidad Nacional de Córdoba, Argentina).

\section{Results and discussion}

The use of by-products such as the citrus pulp silage can be a valuable option not only to reduce the cost of the fish diets but also to provide alternative sources to avoid the use of grains such as wheat, which is consumed by humans. 
In addition, most of the amino acid (AA) values were higher with the citrus pulp diet (CPD), except methionine, lysine. For this reason, the indispensable amino acid/dispensable amino acid (IAA/DAA) ratio was higher in the CPD than in the control diet (CON) (Table 3).

Citrus pulp meal presented a lower nitrogen-free extract and crude energy than the wheat meal, but with higher values than those observed with citrus peel meal (Moreno Alvarez et al. 2000). The bromatological analysis of the CPD exhibited a higher value of crude protein (CP 44.3\%), CL (19.8\%) and CF (3.6\%) in comparison to the CON, although the gross energy (GE) content was lower in comparison to the CON (Table 3). Besides, the CP values of the CPD were higher in orange pulp ( $8.5 \%$ here) than that reported by Lashkari and Taghizadeh (2012) and Rodriguez et al. (2012) (6.2\% in these other studies). This high CP content could be due to the silage procedure that contributed to the increase in protein content due to anaerobic bacteria activity and the bacteria themselves. The amino acid values of the CPD were higher in most of the IAA, except methionine and lysine, which are the most limiting AAs in fish nutrition. Cystine, tyrosine, serine and glutamine were also lower in comparison to the CON values (Table 3).

The inclusion of citrus pulp silage did not affect the growth parameters in sharpsnout sea bream (Table 4), showing that this species can tolerate up to $234 \mathrm{~g} / \mathrm{kg}$ of $\mathrm{CP}(P>0.05)$. Similar results were found by Fukuda et al. (2014) in S. quinqueradiata, with $100 \mathrm{~g} / \mathrm{kg}$ as a maximum
Table 4 Growth and feed efficiency parameters on sharpsnout sea bream fed with the two experimental diets at the end of the trial

\begin{tabular}{lrr}
\hline Parameters & \multicolumn{1}{c}{ Control diet } & \multicolumn{1}{c}{ Citrus pulp diet } \\
\hline Initial weight $(\mathrm{g})$ & $21.87 \pm 0.34$ & $21.07 \pm 0.29$ \\
Final weight $(\mathrm{g})$ & $103.50 \pm 1.29$ & $94.90 \pm 3.32$ \\
${\text { Weight gain }(\%)^{\mathrm{a}}}^{\mathrm{S}}$ & $373.70 \pm 9.96$ & $351.07 \pm 123.66$ \\
${\text { SGR }(\% \text { day })^{\mathrm{b}}}_{\text {TGC }^{\mathrm{c}}}$ & $1.48 \pm 0.02$ & $1.44 \pm 0.03$ \\
FI $\left(\mathrm{g} 100 \mathrm{~g} \mathrm{fish} /\right.$ day $^{\mathrm{d}}$ & $1.77 \times 10^{-3} \pm 0.02$ & $1.68 \times 10^{-3} \pm 0.05$ \\
FCR $^{\mathrm{e}}$ & $2.20 \pm 0.10^{\mathrm{a}}$ & $2.67 \pm 0.02^{\mathrm{b}}$ \\
${\text { PER }(\%)^{\mathrm{f}}}$ & $1.94 \pm 0.09^{\mathrm{a}}$ & $2.31 \pm 0.05^{\mathrm{b}}$ \\
\hline
\end{tabular}

Values are \pm SD of three replications. Data in the same row with different superscripts differ at $(P<0.05)$. Initial weight in each phase was considered as co variable for final weight and SGR

${ }^{\text {a}}$ Weight gain $(\mathrm{WG})=(($ final mean weight - initial mean weight $) \times 100) /$ initial mean weight

${ }^{\mathrm{b}}$ Specific growth rate $\left(\% \mathrm{day}^{-1}\right), \mathrm{SGR}=100 \times \ln ($ final weight/initial weight)/days

${ }^{\mathrm{c}}$ Thermal growth coefficient $(\mathrm{TGC})=$ final weight $1 / 3-$ initial weight $1 / 3] /$ (water temperature - effective temperature)

${ }^{\mathrm{d}}$ Feed intake ratio $\left(\mathrm{g} 100 \mathrm{~g}_{\text {fish }}{ }^{-1} \mathrm{day}^{-1}\right), \mathrm{FI}=100 \times$ feed consumption (g)/average biomass $(\mathrm{g}) \times x$ days

${ }^{\mathrm{e}}$ Feed conversion ratio, FCR $=$ feed offered $(\mathrm{g}) /$ weight gain $(\mathrm{g})$

${ }^{\mathrm{f}}$ Protein efficiency ratio $(\mathrm{PER})=$ weight gain $(\mathrm{g}) /$ protein offered $(\mathrm{g})$
Table 3 Total amino acids of raw material and experimental diets

\begin{tabular}{llllll}
\hline Amino acids & Fish meal & Wheat & $\begin{array}{l}\text { Citrus pulp } \\
\text { silage }\end{array}$ & Control diet & Citrus pulp diet \\
\hline Indispensable amino acids (IAA) & \multicolumn{7}{l}{ expressed in $\%$} \\
Arginine & 6.18 & 0.50 & 0.47 & 3.13 & 3.17 \\
Histidine & 2.66 & 0.28 & 0.18 & 1.24 & 1.22 \\
Isoleucine & 3.54 & 0.42 & 0.34 & 1.93 & 1.95 \\
Leucine & 5.66 & 0.76 & 0.59 & 3.42 & 3.43 \\
Lysine & 4.43 & 0.36 & 0.42 & 3.72 & 3.26 \\
Methionine & 2.04 & 0.14 & 0.14 & 1.30 & 1.21 \\
Phenylalanine & 4.93 & 0.58 & 0.30 & 1.68 & 1.78 \\
Threonine & 3.60 & 0.36 & 0.32 & 1.99 & 1.93 \\
Valine & 3.86 & 0.51 & 0.45 & 2.25 & 2.22 \\
Dispensable amino acids (DAA) expressed in $\%$ & & & \\
Alanine & 4.45 & 0.44 & 0.63 & 2.86 & 2.79 \\
Asparagine & 6.33 & 0.62 & 0.93 & 4.28 & 4.16 \\
Cysteine & 1.40 & 0.44 & 0.13 & 1.44 & 6.20 \\
Glutamine & 8.99 & 3.37 & 0.90 & 6.76 & 2.67 \\
Glycine & 5.36 & 0.52 & 0.52 & 2.67 & 1.99 \\
Proline & 7.06 & 1.27 & 1.17 & 2.00 & 1.19 \\
Serine & 2.98 & 0.55 & 0.47 & 1.93 & 0.93 \\
Tyrosine & 3.60 & 0.15 & 0.19 & 1.29 & \\
IAA/DAA & 0.92 & 0.53 & 0.65 & 0.89 & \\
\hline
\end{tabular}


inclusion. At the same time, Moreno Alvarez et al. (2000) commented that the best growth in Nile tilapia was achieved with a $20 \%$ inclusion of citrus pulp, but Rodriguez et al. (2012) found a detrimental growth in Nile tilapia and Rhamdia quelen, with $300 \mathrm{~g} / \mathrm{kg}$ of citrus pulp inclusion in comparison to broken rice and ground corn.

In contrast, feed efficiency (Table 4) exhibited significant differences, with feed intake (FI) and food conversion rate (FCR) being higher in the fish fed the CPD and lower in the PER $(P<0.05)$. One possible reason for these results could be that the feed efficiency parameters were affected by citrus pulp. This may be due to the presence of soluble fibre in citrus pulp, which could affect nutrient absorption, thereby reducing the feed efficiency (Rodriguez et al. 2012). As Rodriguez et al. (2012) stated, crude fibre (CF) is considered a main anti-nutritional factor. Nevertheless, in the case of $D$. puntazzo, this fish obtained good growth rates, with $7.44 \%$ CF in its diet (Nogales-Mérida et al. 2010). Another possible cause of feed efficiency reduction in this trial could be the presence of limonene in the seeds of citrus pulp, which is harmful to monogastric animals (Göhl 1982 cited by Wadhwa and Bakshi 2013). According to Shimada et al. (2002), the toxicity of limonene metabolites depends on the species; this could be the more plausible cause of the feed efficiency reduction obtained in this trial and in Yellowtail (Fukada et al. 2014) and zebrafish, which were fed with Citrus junos that also contained limonene, among other substances (Zang et al. 2014).

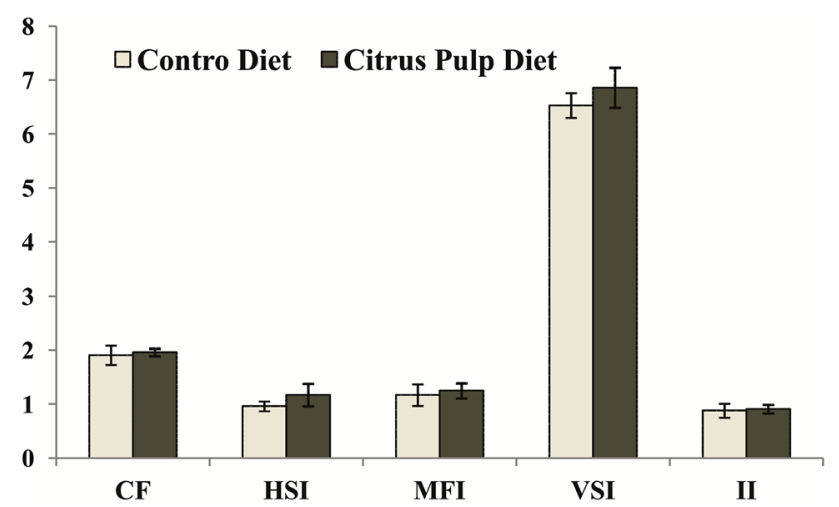

Fig. 1 Biometric values on sharpsnout sea bream at the end of the trial fed with citrus pulp diet and control diet. Values are \pm SD of three replications. Data in the same row with different superscripts differ at $P<0.05$. Condition factor $(\mathrm{CF})=$ [body weight $(\mathrm{g}) /$ fork length $\left.(\mathrm{cm})^{3}\right] \times 100$. Viserosomatic index $(\mathrm{VSI})=100 \times[$ visceral weight $(\mathrm{g}) /$ fish weight $(\mathrm{g})]$. Mesenteric fat index $(\mathrm{MF})=[$ mesenteric fat weight $(\mathrm{g}) /$ body weight $(\mathrm{g})] \times 100$. Hepatosomatic index $($ HSI $)=[$ liver weight $(\mathrm{g}) /$ body weight $(\mathrm{g})] \times 100$. Gonadosomatic index $(\mathrm{GSI})=100 \times[$ gonads weight $(\mathrm{g}) /$ fish weight $(\mathrm{g})]$
Regarding the biometric parameters, all these values did not present statistical differences (Fig. 1). Nevertheless, it was observed high values in HSI and VFI in fish fed CPD in comparison to CON. It seems that CPD induced fat deposition in the viscera as well as in the liver, which could reduce the fat content in the carcass in comparison to the CON. Rodriguez et al. (2012) found similar results, and they suggested that part of the energy coming from starch (the CON) was used for lipid biosynthesis, which seems to be the case with sharpsnout sea bream fed the CON.

For body composition, the fish fed the CPD exhibited higher moisture and a lower quantity of crude lipid than sharpsnout sea bream fed the CON $(P>0.05)$. In the case of crude protein efficiency and gross energy efficiency were not observed statistical differences between the two treatments (Table 5). Analysing the protein and energy retention in sharpsnout sea bream, this was markedly affected by citrus pulp inclusion, showing the detrimental effect of this raw material had in this species. According to Lashkari and Taghizadeh (2012), only $11.54 \%$ of citrus pulp was protein, while the rest was associated with neutral detergent soluble protein and with neutral and acidic detergent insoluble proteins that are not available to monogastric animals. This phenomenon could affect the protein and energy deposition in the carcass as well as the protein retention. At the same time, we observed a reduction in the real protein content of the CPD (94.68\%) in comparison to the CON (96.74\%). Pectin could also play a detrimental role in crude protein efficiency as Krogdahl et al. (2005) indicated that this nonstarch polysaccharide may inhibit protein hydrolysis.

The amino acid composition of the carcasses did not exhibit significant differences at the end of the experiment between the two diets. Nevertheless, comparing the results

Table 5 Body composition and retention of sharpsnout sea bream fed with wheat diet $(\mathrm{CON})$ and citrus pulp diet $(\mathrm{CP})$

\begin{tabular}{lccc}
\hline Parameter & Initial & Control diet & Citrus pulp diet \\
\hline Moisture (\%) & 67.77 & $64.05 \pm 1.56^{\mathrm{b}}$ & $66.31 \pm 0.59^{\mathrm{a}}$ \\
Crude protein (CP \% ww) & 16.00 & $16.82 \pm 0.43$ & $16.97 \pm 0.37$ \\
Crude lipid (CL \% ww) & 12.05 & $15.44 \pm 1.25^{\mathrm{b}}$ & $11.30 \pm 1.26^{\mathrm{a}}$ \\
Ash (\% ww) & 4.57 & $3.57 \pm 0.25$ & $3.72 \pm 0.33$ \\
CPE (\%) & & $22.90 \pm 1.29^{\mathrm{b}}$ & $18.44 \pm 0.64^{\mathrm{a}}$ \\
GEE $(\%)^{\mathrm{B}}$ & & $26.49 \pm 2.87^{\mathrm{b}}$ & $18.52 \pm 1.87^{\mathrm{a}}$ \\
\hline
\end{tabular}

Values are \pm SD of three replications. Data in the same row with different superscripts differ at $(P<0.05)$

${ }^{\mathrm{A}}$ Crude protein efficiency, CPE $(\%)=($ increment of protein corporally, g) $\times 100 /$ (ingestion protein, g)

${ }^{\mathrm{B}}$ Gross energy efficiency, GEE $(\%)=(\%)$ (increment of energy corporally, $\mathrm{kJ}) \times 100 /($ ingestion of energy, $\mathrm{kJ}$ ) 
Table 6 Essential amino acids of the carcass of sharpsnout sea bream at the beginning and at the end of the experiment

\begin{tabular}{lccc}
\hline & Initial fish & Control diet & Citrus pulp diet \\
\hline $\begin{array}{l}\text { Indispensable amino acids (IAA) } \\
\text { fish (wet weight) }\end{array}$ & & & \\
Arginine & 1.17 & $1.43 \pm 011$ & $1.22 \pm 0.09$ \\
Histidine & 0.34 & $0.48 \pm 0.11$ & $0.43 \pm 0.03$ \\
Isoleucine & 0.54 & $0.64 \pm 0.04$ & $0.67 \pm 0.02$ \\
Leucine & 1.03 & $1.14 \pm 0.11$ & $1.19 \pm 0.06$ \\
Lysine & 1.18 & $1.29 \pm 0.16$ & $1.44 \pm 0.32$ \\
Methionine & 0.45 & $0.50 \pm 0.09$ & $0.47 \pm 0.06$ \\
Phenylalanine & 0.52 & $0.66 \pm 0.08$ & $0.62 \pm 0.07$ \\
Threonine & 0.60 & $0.75 \pm 0.11$ & $0.71 \pm 0.03$ \\
Valine & 0.60 & $0.73 \pm 0.06$ & $0.76 \pm 0.05$ \\
Dispensable amino acids (DAA) & contain calculated on $\mathrm{g} / 100 \mathrm{~g}$ of \\
fish (wet weight) & & & \\
Alanine & 0.91 & $1.07 \pm 0.14$ & $1.02 \pm 0.23$ \\
Asparagine & 1.43 & $1.61 \pm 0.20$ & $1.63 \pm 0.32$ \\
Cysteine & 0.32 & $0.34 \pm 0.08$ & $0.32 \pm 0.06$ \\
Glutamine & 2.08 & $2.25 \pm 0.26$ & $2.33 \pm 0.45$ \\
Glycine & 1.13 & $1.43 \pm 0.16$ & $1.13 \pm 0.32$ \\
Proline & 0.63 & $0.74 \pm 0.10$ & $0.66 \pm 0.14$ \\
Serine & 0.60 & $0.78 \pm 0.13$ & $0.68 \pm 0.06$ \\
Tyrosine & 0.43 & $0.55 \pm 0.09$ & $0.51 \pm 0.09$ \\
IAA/DAA & 0.88 & $0.87 \pm 0.03$ & $0.92 \pm 0.12$ \\
\hline
\end{tabular}

Values are $\pm \mathrm{SD}$ of three replications

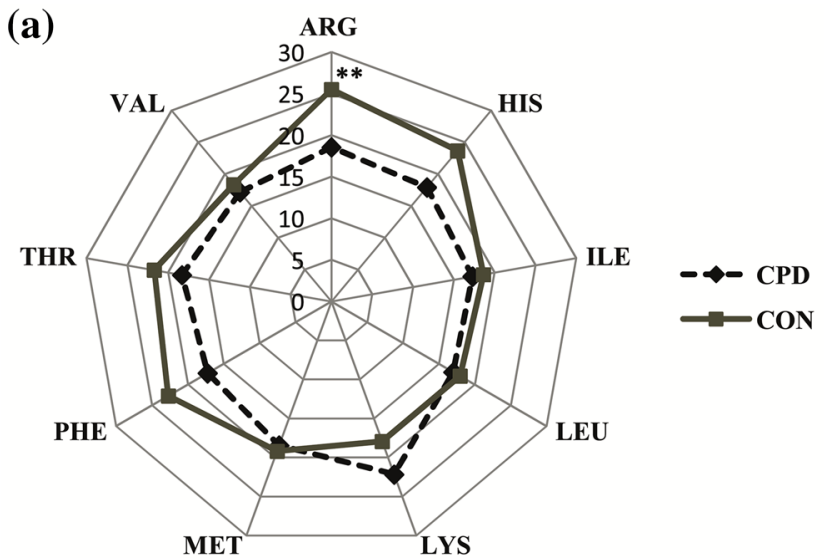

Fig. 2 a Indispensable amino acid (IAA) retention of sharpsnout seabream fed with CON and CPD. Values are \pm SD of three replications. Data with double asterisk differ at $P<0.01$. b Dispensable amino acid with the values of the composition of the initial fishes, there was an increase in all of the amino acid values (Table 6).

For amino acid retention, there were only significant differences between treatments in Arginine, being fish fed CON that obtained the highest value (Fig. 2a, b). This reduction in this IAA could be caused as a result of the association to neutral and acidic detergent insoluble proteins (Lashkari and Taghizadeh 2012), which are not available for fish consumption. This outcome caused a decrease in the AA retention of sharpsnout sea bream, especially in arginine, that presented significant differences $(<0.01)$.

\section{Conclusion}

The inclusion of $234 \mathrm{~g} / \mathrm{kg}$ of citrus pulp silage in the diet of $D$. puntazzo did not influence the final weight gain and the amino acid profile, although it did result in a reduction in feed efficiency and protein and energy retention, which may have been due to the presence of limonene or pectin, compounds that affect the absorption of nutrition. The citrus pulp silage is a good alternative source not only as an energy source but also as a protein source for omnivorous fish.

Citrus pulp as an energy source in marine fish nutrition has not been studied previously, and for that reason, the aim of this experiment was to study the use of citrus pulp silage in juveniles of D. puntazzo, observing the growth, feed

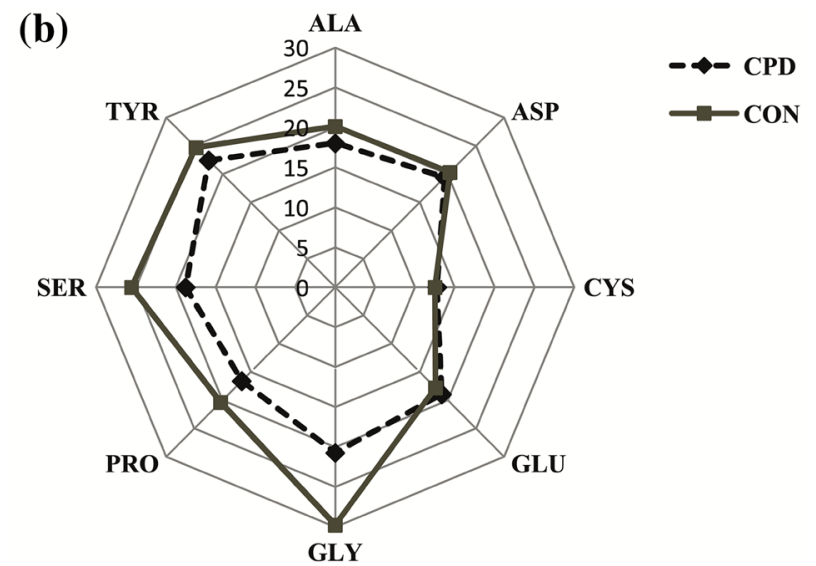

(DAA) retention of sharpsnout seabream fed the CON and CPD. Values are \pm SD of three replications 
efficiency and biometric parameters, as well as the amino acids, profile, and retention.

\section{Compliance with ethical standards}

Conflict of interest The authors do not have any conflict of interest.

Open Access This article is distributed under the terms of the Creative Commons Attribution 4.0 International License (http://creativeco mmons.org/licenses/by/4.0/), which permits unrestricted use, distribution, and reproduction in any medium, provided you give appropriate credit to the original author(s) and the source, provide a link to the Creative Commons license, and indicate if changes were made.

\section{References}

Alnaimy A, Gad AE, Mustafa MM, Atta MAA, Basuony HAM (2017) Using of citrus by-products in farm animals feeding. J Sci 1(3):58-67. https://doi.org/10.15406/oajs.2017.01.00014

Amorim AB, Thomaz MC, Ruiz US, Pascoal LAF, Watanabe PH, Martinez JF, Daniel E, Martins MIEG, Masson GCIH (2011) Economic evaluation of the use of different levels of citrus pulp with or without the addition of enzyme complex in the diets of pigs. Arq Bras Med Vet Zootec 63(5):1181-1190. https://doi. org/10.1590/S0102-09352011000500020

Amorim AB, Thomaz MC, Ruiz U, Dott S, Martinez JF, Pascoal LAF, Daniel E, Watanabe PH, Rosalen DL (2014) Citrus pulp and enzyme complex for growing and finishing pigs. Rev Bras Saúde Prod Anim Salv 15(2):369-380. https://doi.org/10.1590/S1519 $-99402014000200009$

AOAC (Association of official Analytical Chemists) (1990) Official methods of analysis, 15th edn. Association of Official Analytical Chemists, Arlington

Basir R, Toghyani M (2017) Effect of dietary graded levels of dried lemon (Citrus aurantifulia) pulp on performance, intestinal morphology and humoral immunity in broiler chickens. Int J Recycl Org Waste Agric 6:125-132. https://doi.org/10.1007/s4009 3-017-0159-5

Bosch L, Alegria A, Farré R (2006) Application of the 6-aminoquinolyl- $N$-hydroxysuccinimidyl carbamate (AQC), reagent to the RP-HPLC determination of amino acids in infant foods. J Chromatogr B 831:176-183. https://doi.org/10.1016/j.jchro mb.2005.12.002

Chaouch H, Hamida OBA-BH, Ghorbel M, Jarboui O (2013) Diet composition and food habits of Diplodus puntazzo (Sparidae) from the Gulf of Gabès (Central Mediterranean). J Mar Biol Assoc UK 93(8):2257-2264. https://doi.org/10.1016/j.jchromb.2005.12.002

Crosswhite JD, Myers NB, Adesogan AT, Brendemuhi JH, Johnson DD, Carr CC (2013) The effect of dietary citrus pulp on the growth, feed efficiency, carcass merit, and lean quality of finishing pigs. Prof Animal Sci 29:345-358

Food and Agriculture Organization (FAO) (2017) Citrus fruit, fresh and processed. Statistical bulletin 2016. Trade and Markets Division, Rome

Francis G, Makker HPS, Becker K (2001) Antinutritional factors present in plant-derived alternate fish ingredients and their effects in fish. Aquaculture 199:197-227. https://doi.org/10.1016/S0044 -8486(01)00526-9

Fukada H, Furutani T, Shimizu R, Masumoto T (2014) Effects of yuzu (Citrus junos) peel from waste as an aquaculture feed supplement on growth, environmental load, and dark muscle discoloration in yellowtail Seriola quinqueradiata. J Aquat Food Prod T 23:511521. https://doi.org/10.1080/10498850.2012.732201

Hernández MD, Egea MA, Rueda FM, Aguado F, Martínez FJ, García B (2001) Effects of commercial diets with a different $P / E$ ratio on sharpsnout sea bream (Diplodus puntazzo) growth and nutrient utilization. Aquaculture 195:321-329. https://doi.org/10.1016/ S0044-8486(00)00564-0

Krogdahl ^, Hemre G-I, Mommsen TP (2005) Carbohydrates in fish nutrition: digestion and absorption in postlarval stages. Aquacult Nutr 11(2):103-122. https://doi.org/10.111 1/j.1365-2095.2004.00327.x

Lashkari S, Taghizadeh A (2012) Nutrient digestibility and evaluation of protein and carbohydrate fractionation of citrus by-products. J Anim Physiol Anim Nutr 97:701-709. https://doi.org/10.111 1/j.1439-0396.2012.01312.x

Marín FR, Soler-Rivas C, Benavente-García O, Castillo J, Pérez-Alvarez JA (2007) By-products from different citrus processes as a source of customized functional fibres. Food Chem 100:736-741. https://doi.org/10.1016/j.foodchem.2005.04.040

Moreno Alvarez MJ, Hernández JG, Rovero R, Tablante A, Rangel L (2000) Alimentación de tilapias con raciones parciales de cáscaras de naranja. Cienc Technol Aliment 3(1):29-33. http://www.redal yc.org/articulo.oa?ld=72430204

Mourão JL, Pinheiro VM, Pratesm JAM, Bessa RJB, Ferreira LMA, Fontes CMGA, Ponte PIP (2008) Effect of dietary dehydrated pasture and citrus pulp on the performance and meat quality of broiler chickens. Poult Sci 87:733-743. https://doi.org/10.3382/ ps.2007-00411

Nogales-Mérida S, Tomás-Vidal A, Martínez-Llorens S, Jover Cerdá M (2010) Sunflower meal as a partial substitute in juvenile sharpsnout sea bream (Diplodus puntazzo) diets: amino acid retention, gut and liver histology. Aquaculture 298:275-281. https://doi. org/10.1016/j.aquaculture.2009.10.025

Oluremi OIA, Okafor FN, Adenkola AY, Orayaga KT (2010) Effect of fermentation of sweet orange (Citrus sinensis) fruit peel on its phytonutrients and the performance of broiler starter. Int J Poult Sci 9(6):546-549

Piquer Querol O (2006) Whole citrus fruits in sheep nutrition. Dissertation, Universitat Politècnica de València

Piquer O, Ródenas L, Casado C, Blas E, Pascual JJ (2009) Whole citrus fruits as an alternative to wheat grain or citrus pulp in sheep diet: effect on the evolution of ruminal parameters. Small Rumin Res 83:14-21. https://doi.org/10.1016/j.smallrumres.2008.11.009

Rodriguez APO, Gominho-Rosa MDC, Cargnin-Ferreira E, De Francisco A, Fracalossi DM (2012) Different utilization of plant sources by the omnivores jundiá catfish (Rhamdia quelen) and Nile tilapia (Oreochromis niloticus). Aquacult Nutr 18:65-72. https://doi.org/10.1111/j.1365-2095.2011.00877.x

Saleh HM, El-Mor M (2015) Feeding habits of the sharp snout sea bream, Diplodus puntazzo (Cetti, 1777) (Teleostei: Sparidae) from Benghazi Coast, Eastern Libya. Int J Bioassays 4:3860-3865

Shan Y (2017) Comprehensive utilization of citrus by-products. Academic Press, Amsterdam

Shimada T, Shindu M, Miyazawa M (2002) Species differences in the metabolism of $(+)-$ and $(-)-$ Limonenes and their metabolites, carveols and carvones, by cytochrome P450 enzymes in liver microsomes of mice, rats, guinea pigs, rabbits, dogs monkeys, and humans. Drug Metab Pharmacokin 17(6):507-515

Silva VK, Souza Morita V, Boleli IC (2013) Effect of pectin extracted from citrus pulp on digesta characteristics and nutrient digestibility in broilers chickens. R Bras Zootec 42(8):575-583. https ://doi.org/10.1590/S1516-35982013000800007

Spreen TH (2001) Projections of world production and consumption of citrus to 2010. In: China/FAO citrus symposium, Beijing, Popular Republic of China, 14-17 May 2001 
Wadhwa M, Bakshi MPS (2013) Fruit wastes as livestock feed. In: Makkar HPS (ed) Utilization of fruit and vegetable wastes as livestock feed and as substrates for generation of other value-added products. In: RAP publication 2013/04 FAO, APHCA, pp 11-14

Wang C, Gao GL, Huang JX, Zhang KS, Zhong H, Wang HW, Su J, Xie M, Wang QG (2017) Nutritive value of dry citrus pulp and its effect on performance in geese from 35 to 70 days of age. $\mathrm{J}$ Appl Poult Res 26:253-259. https://doi.org/10.3382/japr/pfw069

Watanabe PH, Thomaz MC, Martins MIEG, Ruiz US, Fraga AL, Santos VM, Pascoal LAF, Silva SZ (2009) Gross and partial net incomes and feeding cost of diets containing citrus pulp for pigs slaughtered with $130 \mathrm{~kg}$ of weight. Arq Bras Med Vet Zootec 61(1):203-210. https://doi.org/10.1590/S0102-09352009000100029
Watanabe PH, Thomas MC, Ruiz US, Santos VM, Masson GCI, Fraga AL, Pascoal LAF, Robes-Huaynate RA, Silva SZ (2010) Carcass characteristics and meat quality of heavy swine fed different citrus pulp levels. Arq Bras Med Vet Zootec 62(4):921-929. https://doi. org/10.1590/S0102-09352010000400023

Zang L, Shimada Y, Kawajiri J, Tanaka T, Nishimura N (2014) Effect of yuzu (Citrus junos Siebold ex Tanaka) peel on the diet-induced obesity in a zebrafish model. J Funct Foods 10:499-510. https:// doi.org/10.1016/j.jff.2014.08.002

Publisher's Note Springer Nature remains neutral with regard to jurisdictional claims in published maps and institutional affiliations. 